\title{
Evaluation of Antidiabetic Activity of Hydroalcoholic Extract of Cassia fistula Linn. pod in Streptozotocin-Induced Diabetic Rats
}

\author{
Ram Niwas Jangir, Gyan Chand Jain*
}

\section{Ram Niwas Jangir, Gyan Chand Jain*}

Centre for Advanced Studies, Department of Zoology, University of Rajasthan, Jaipur, Rajasthan, INDIA.

\section{Correspondence}

Prof. Gyan Chand Jain, Centre for Advanced Studies, Department of Zoology, University of Rajasthan, Jaipur, Rajasthan INDIA.

Tel.: 09414050105

E-mail: gcjzoology@gmail.com

\section{History}

- Submission Date: 04-03-2017

- Review completed: 23-03-2017;

- Accepted Date: 30-05-2017

DOI : 10.5530/pj.2017.5.95

Article Available online

http://www.phcogj.com/v9/i5

\section{Copyright}

(C) 2017 Phcog.Net. This is an openaccess article distributed under the terms of the Creative Commons Attribution 4.0 International license.

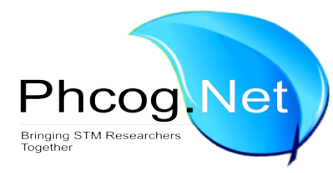

\begin{abstract}
Background: Diabetes mellitus (DM) is a global health problem and the incidence of DM is increasing at alarming rate all over the world. Many Indian medicinal plants have been reported to possess potential antidiabetic activity and could play important role in the management diabetes. Objective: The present study aimed to evaluate antidiabetic activities of $70 \%$ ethanolic extract of Cassia fistula pod in streptozotocin-induced diabetic rats. Materials and Methods: Diabetes was induced in male Wistar rats by single intraperitoneal injection of streptozotocin (60 mg/kg b.wt.). The diabetic rats were administered orally with C. fistula pod extract at three different doses $(100,250$ and $500 \mathrm{mg} / \mathrm{kg}$ b.wt./day) for 60 days. The results were compared with standard drug glibenclamide $(5 \mathrm{mg} / \mathrm{kg} \mathrm{b}$.wt./day) treated rats. Results: The streptozotocin treated diabetic control rats showed a significant increase in the blood glucose and glycosylated hemoglobin ( $\mathrm{HbA} 1 \mathrm{c}$ ) levels with a concomitant decrease in the body weight and glycogen content in the liver as compared to normal control rats. Oral administration of $C$. fistula pod extract $(100,250$ and $500 \mathrm{mg} / \mathrm{kg}$ b.wt./day) or glibenclamide for 60 days showed significant reduction in the blood glucose and $\mathrm{HbA} 1 \mathrm{c}$ levels and an elevation in the body weight and hepatic glycogen content as compared to diabetic control rats. Furthermore, treatment with extract $(500 \mathrm{mg} / \mathrm{kg}$ b.wt.) also showed improvement of oral glucose tolerance test (OGTT) in diabetic rats. These results were comparable to glibenclamide. Conclusion: The results of present study showed that $C$. fistula pod extract possess significant antihyperglycemic activity and supports the traditional use of $C$. fistula pod for the treatment of diabetes mellitus.
\end{abstract}

Key words: Antidiabetic, Blood glucose, Cassia fistula, Glycogen, Glycosylated hemoglobin, Streptozotocin.

\section{INTRODUCTION}

Diabetes mellitus (DM) is a chronic complicated metabolic disorder characterized by increased blood glucose level resulting from the defects in insulin secretion, insulin action, or both. Hyperglycemia is suggested to be one major cause contributing to diabetic complication. ${ }^{1}$ The incidence of DM is rising at alarming rate all over the word in the coming years. According to the diabetic atlas of the International Diabetic Federation, 382 million people were affected by diabetes worldwide in the year 2013 and diabetes prevalence is expected to 592 million by the year 2035. ${ }^{2}$ The World Health Organization projects that diabetes will be the 7th leading cause of death in $2030 .{ }^{3}$

Management of diabetes is a global health problem and successful treatment is yet to be discovered. ${ }^{4} \mathrm{Cur}-$ rently available therapies for diabetes include insulin and various oral antidiabetic agents such as sulfonylureas, biguanides and glinides. Many of them have a number of serious adverse effects; therefore, the search for more effective and safer hypoglycemic agents is one of the important areas of investigation. ${ }^{5}$ Medicinal plants are rich source of various bioactive phytochemicals. Many Indian medicinal plants have been found to be useful in the management of diabetes acting though variety of mechanisms. Medicinal plants provide better alternatives as they are less toxic, easily available and affordable and many of the currently available drugs have been derived directly or indirectly from them. ${ }^{6,7}$

Cassia fistula Linn. (Hindi-Amaltas; EnglishGolden Shower or Indian Laburnum), a medium sized tree belonging to the family-Caesalpiniaceae, is cultivated throughout India as an ornamental plant and is used widely for its medicinal properties. Almost every part of $C$. fistula are used extensively in the folklore medicine for the treatment of a variety of diseases. ${ }^{89}$ The dried pod and pulp are valued for their laxative properties. The pulp is considered a safe purgative, recommended for pregnant women and children to relieve disorders of the liver and biliousness. It is a remedy for malaria and black water fever. It is also used to treat leprosy and diabetes and removal of abdominal obstructions. The slightly sweet seeds pos-

Cite this article : Jangir RN, Jain GC. Evaluation of antidiabetic activity of hydroalcoholic extract of Cassia fistula Linn. pod in streptozotocin-induced diabetic rats. Pharmacog J. 2017;9(5):599606. 
sess laxative, carminative, cooling and antipyretic properties. They are also used to relieve constipation and to treat jaundice, biliousness, skin disease and swollen throat. ${ }^{10}$ The plant has been reported to possess various pharmacological activities such as anticancer, ${ }^{11}$ antifertility, ${ }^{12}$ antifungal, ${ }^{13}$ antihelmintic, ${ }^{14}$ antihyperlipidemic, ${ }^{15}$ anti-inflammatory, ${ }^{16}$ Antipyretic activity, ${ }^{17}$ antioxidant, ${ }^{18}$ antimicrobial, ${ }^{19}$ hepatoprotective,${ }^{20}$ immunomodulatory, ${ }^{21}$ and laxative effects. ${ }^{22}$

Phytochemical studies revealed that the edible fruit tissue of the Indian laburnum is a rich source of potassium, calcium, iron, manganese and also of aspartic acid, glutamic acid and lysine amino acids. ${ }^{9}$ The seeds of the plant are rich in glycerides with linoleic, oleic, stearic and palmitic acids as major fatty acids together with traces of caprylic and myristic acids and carbohydrates like galactomannan. ${ }^{23,24}$ Pods contained flavon-3-ol and proanthocyanidins like catechin, epiafzelechin, epicatechin, procyanidin B-2, ${ }^{25}$ rhein; 1,8-dihydroxy-3-anthraquinone carboxylic, ${ }^{26}$ fistulic acid, ${ }^{27}$ 3-formyl-1- hydroxy-8-methoxy anthraquinone, ${ }^{28}$ diterpene; $3 \beta$-hydroxy-17-norpimar-8(9)-en-15-one, ${ }^{29} 5$-Nonatetracontanone, 2 -hentriacontanone, triacontane, 16 -hentriacontanone and $\beta$-sitosterol, ${ }^{30}$ kaempferol and dihydrokaempferol. ${ }^{31}$ Recently presence of quercetin dehydrates has also been confirmed by Laxmi et al, (2015). ${ }^{19}$ Oxyanthraquinones, chrysophanol and chrysophanein, were also isolated from the seeds of C. fistula by Kuo et al., (2002). ${ }^{32}$

Antihyperglycemic activity of C. fistula roots, ${ }^{33}$ bark, ${ }^{34-37}$ leaves ${ }^{38,39}$ and flowers, ${ }^{40,41}$ has been reported in diabetic animals by various workers. But reports on antidiabetic activity of $C$. fistula pods are very scanty. ${ }^{42}$ Moreover, in traditional medicine, the pods of $C$. fistula are used in the treatment of diabetes. ${ }^{43}$ Thus the present study was undertaken to investigate the antidiabetic efficacy of $70 \%$ ethanolic extract of $C$. fistula pod in streptozotocin induced diabetic rats.

\section{MATERIAL AND METHODS}

\section{Plant material and preparation of extract}

Fresh pods of C. fistula were collected in the months April-May, 2013, from the campus of University of Rajasthan, Jaipur. The plant was taxonomically identified by Prof. K.P. Sharma, Incharge, Herbarium, Department of Botany, University of Rajasthan, Jaipur, India where a voucher specimen (Specimen no. RUBL21057) was deposited. The fresh pods were washed with distilled water, shade dried, and powdered in an electric grinder. The powder (300 g) was suspended in 70\% ethanol and allowed to stand for $24 \mathrm{~h}$. The mixture was subjected to soxhlet apparatus for extraction at $60^{\circ} \mathrm{C}-70^{\circ} \mathrm{C}$ for $35 \mathrm{~h}$. It was then filtered using a filter paper and the filtrate was evaporated to dryness in an oven at $40^{\circ} \mathrm{C}$. A brownish residue weighing $38.5 \mathrm{~g}$ ( $12.83 \%$ of dried powder) was obtained. This was kept in an air tight bottle in a refrigerator until used. The extract was suspended in water before administering to experimental animals.

\section{Animals}

Colony bred, adult, healthy, male rats of Wistar strain (Rattus norvegicus) weighing 170-200 g were used in the present study. The animals were housed in polypropylene cages under standard husbandry conditions (12 h light / dark cycle; $25 \pm 3^{\circ} \mathrm{C}$ temperature). Rats were provided with water and nutritionally adequate pellet diet (Aashirwad Food Industries, Chandigarh, India) ad libitum. The animals were maintained as per guidelines of the Committee for the Purpose of Control and Supervision of Experiments on Animals (CPCSEA). The study was approved by the Animal Ethical Committee of the Centre of Advanced studies, Department of Zoology, University of Rajasthan, Jaipur (India).

\section{Chemicals}

Streptozotocin was obtained from Himedia Laboratory limited, Mumbai, India. Glibenclamide tablets (Daonil; Aventis Pharma. Ltd., India) were purchased from the medical store. All other chemicals and reagents used were of analytical grade.

\section{Experimental induction of diabetes}

Diabetes mellitus was induced by a single intraperitoneal injection of streptozotocin (STZ) dissolved in citrate buffer ( $\mathrm{pH} \mathrm{4.5)}$ at a dose of $60 \mathrm{mg} / \mathrm{kg}$ body weight into overnight fasted rats. The STZ treated animals were given $2 \%$ glucose solution for $24 \mathrm{~h}$ after $5 \mathrm{~h}$ of STZ injection to prevent initial drug induced hypoglycemic mortality. Development of diabetes was verified after one week of STZ injection by measuring the blood glucose level in blood samples obtained from the tail vein of overnight fasted rats. The rats having blood glucose level above $250 \mathrm{mg} / \mathrm{dl}$ were considered to be diabetic and used in the study. This day was considered as the zero ( 0 ) day of the experiment.

\section{Experimental design}

The rats were divided into six different groups, each consisting of six animals and treated as follows:

Group I: Control rats receiving vehicle $(0.5 \mathrm{ml}$ distilled water $/ \mathrm{rat} / \mathrm{day})$ orally for 60 days.

Group II: Diabetic rats receiving vehicle ( $0.5 \mathrm{ml}$ distilled water $/ \mathrm{rat} / \mathrm{day})$ orally for 60 days.

Group III: Diabetic rats receiving C. fistula extract (100 mg/kg b.wt./ day) orally for 60 days.

Group IV: Diabetic rats receiving C. fistula extract $(250 \mathrm{mg} / \mathrm{kg}$ b.wt./ day) orally for 60 days.

Group V: Diabetic rats receiving C. fistula extract ( $500 \mathrm{mg} / \mathrm{kg}$ b.wt./day), orally for 60 days.

Group VI: Diabetic rats receiving glibenclamide standard drug $(5 \mathrm{mg} / \mathrm{kg}$ b.wt./day) orally for 60 days.

\section{Autopsy}

After 24 hours of the last treatment, all the overnight fasted animals of different groups were weighed and autopsied under mild ether anesthesia. Blood was collected directly by cardiac puncture of which $2 \mathrm{ml}$ was added to an anticoagulant vial for the estimation of parameters in blood. The remaining blood sample was allowed to clot and serum was separated and stored at $-20{ }^{\circ} \mathrm{C}$ for future use. The vital organs from each rat were dissected out, cleaned off from adherent fat and blood clot and weighed on a digital electronic balance. Half of the tissues were fixed in Bouin's fixative and remaining half were kept frozen at $-20{ }^{\circ} \mathrm{C}$ for future use.

\section{Body weight}

Body weights of the control and treated rats were recorded prior to STZ injection and than 1 week after STZ induction (0 day of experiment). Body weights were further recorded at 15 day interval for a period of 60 days.

\section{Determination of blood glucose}

Blood samples were collected from the tail vein of overnight fasting rats and basal blood glucose levels were determined prior to STZ injection and than 1 week after STZ induction (0 day of experiment) by using a glucometer (One Touch Ultra blood monitoring system from Life Scan, Johnson and Johnson Company, California, USA). Fasting blood glucose levels of control, diabetic and treated rats were further determined at 15 day interval for a period of 60 days. 


\section{Oral glucose tolerance test (OGTT)}

At the 55 days of experimental period, oral glucose tolerance test (OGTT) was performed in control, diabetic, C. fistula (high dose $500 \mathrm{mg} / \mathrm{kg}$ ) and glibenclamide treated groups. After overnight fasting blood glucose level was estimated (0 minutes). Without delay, a glucose solution ( $2 \mathrm{gm} / \mathrm{kg}$ b.wt.) was administered orally. Blood samples were taken from the tail vein at 30, 60, 90 and 120 mins after glucose administration and blood glucose level were monitored.

\section{Glycosylated hemoglobin, hemoglobin and glycogen}

Glycosylated hemoglobin (HbA1c) was estimated by glycohemoglobin reagent set (Accurex Biomedical Pvt. Ltd. Mumbai, India) and total hemoglobin $(\mathrm{Hb})$ concentration by using Sahli's apparatus. For estimation of glycogen, liver tissue samples were carefully dissected out and stored at $-20^{\circ} \mathrm{C}$ until biochemical analysis. ${ }^{44}$

\section{Statistical analysis}

All the data are expressed as mean \pm SEM. The data were statistically analyzed with one way ANOVA followed by Tukey's as a post hoc test using version 20.0 of IBM SPSS statistics software. Differences in the means were considered significant at $\mathrm{p} \leq 0.05$.

\section{RESULTS}

\section{Body weight}

Changes in body weight of the normal control, diabetic control and experimental rats are depicted in Table 1. The mean body weight of the rats of normal control group was significantly elevated by $7.22 \%$ $(\mathrm{P} \leq 0.05), 10.12 \%(\mathrm{P} \leq 0.01), 16.65 \%(\mathrm{P} \leq 0.001)$ and $23.34 \%(\mathrm{P} \leq 0.001)$ respectively after the $15,30,45$ and 60 days of treatment period when compared to their initial body weight. In contrast to this, the mean body weight of untreated diabetic control rats (group II) was significantly decreased by $5.57 \%(\mathrm{P} \leq 0.05), 9.38 \%(\mathrm{P} \leq 0.001), 13.47 \%(\mathrm{P} \leq 0.001)$ and $15.61 \%(\mathrm{P} \leq 0.001)$ respectively after the $15,30,45$ and 60 days of experimental period when compared with their initial body weight (0 day).

Diabetic rats treated with $C$. fistula pod extract at different doses (100, 250 and $500 \mathrm{mg} / \mathrm{kg}$ b.wt./day) showed duration dependent increase in the mean body weight when compared to their initial body weight but it was comparatively less than that of normal control rats. At low dose treatment (group III) a significant gain $(5.63 \%, \mathrm{P} \leq 0.05)$ in the body weight was observed only after 60 days period. In medium dose group (group IV) a significant gain of $6.07 \%(\mathrm{P} \leq 0.05)$ and $8.46 \%(\mathrm{P} \leq 0.01)$ in body weight was observed after both 45 and 60 days of treatment respectively. The rats of highest dose group showed significant gain in body weight after 30 days $(\mathrm{P} \leq 0.05,3.57 \%), 45$ days $(\mathrm{P} \leq 0.05,9.95 \%)$ and 60 days $(\mathrm{P} \leq 0.001,12.94 \%)$ of treatment compared with their initial body weight ( 0 day). In diabetic rats treated with glibenclamide (group VI), the body weight gain recorded was $7.71 \%(\mathrm{P} \leq 0.05), 10.25 \%(\mathrm{P} \leq 0.01)$ and $14.29 \%(\mathrm{P} \leq 0.001)$ respectively after 30,45 and 60 days of treatment period as compared with their initial body weight ( 0 day).

\section{Blood glucose}

Changes in fasting blood glucose level in normal control and experimental rats are depicted in Table 2. Normal control rats (group I) showed sustained blood glucose level throughout the experimental period. In contrast to this, continuous increase in fasting blood glucose levels was recorded in untreated diabetic control rats (group II) by $5.42 \%$, 9.44\% and $13.27 \%(\mathrm{P} \leq 0.05)$ and $16.40 \%(\mathrm{P} \leq 0.01)$ respectively after 15 , 30,45 and 60 days of experiment period as compared with their corresponding values on 0 day.

The fasting blood glucose levels in diabetic rats treated with 100, 250 and $500 \mathrm{mg} / \mathrm{kg}$ b.wt./day doses of C. fistula pod extract showed significant dose dependent decline after 15, 30, 45, and 60 days of treatment except in lower dose group where significant decline in blood glucose level recorded only after 30 days. The reduction in blood glucose level observed in the C. fistula extract $(100,250$ and $500 \mathrm{mg} / \mathrm{kg})$ treated rats on 60 days treatment duration was $37.25 \%, 43.97 \%$ and $50.13 \%$ respectively.

In diabetic rats receiving glibenclamide treatment (group VI), the fasting blood glucose level also reduced significantly $(\mathrm{P} \leq 0.001)$ by $38.77 \%$, $53.34 \%, 61.32$ and $62.84 \%$ respectively after $15,30,45$ and 60 days of treatment as compared with corresponding values on 0 days.

\section{Oral glucose tolerance test (OGTT)}

Figure 1 shows the changes in the blood glucose levels in normal control and different experimental groups after oral administration of glucose $(2 \mathrm{~g} / \mathrm{kg}$ b.wt.). In all experimental groups oral feeding of glucose induced a significant elevation in blood glucose after 30 minutes as compared with corresponding values on $0 \mathrm{~min}$. After $120 \mathrm{~min}$ the blood glucose

Table 1: Effects of $C$. fistula pod extract on body weight $(g)$ in STZ-induced diabetic rats

\begin{tabular}{|c|c|c|c|c|c|c|}
\hline Treatment & $\begin{array}{c}\text { STZ Treatment } \\
\text { Day }\end{array}$ & $0^{\text {th }}$ day & $15^{\text {th }}$ Day & $30^{\text {th }}$ Day & $45^{\text {th }}$ Day & $60^{\text {th }}$ Day \\
\hline Group I & $186.67 \pm 3.33$ & $189.17 \pm 3.75$ & $\begin{array}{c}202.83 \pm 2.30^{\mathrm{a}} \\
\quad(+7.22)\end{array}$ & $\begin{array}{c}208.33 \pm 3.88^{b} \\
\quad(+10.12)\end{array}$ & $\begin{array}{c}220.67 \pm 3.16^{c} \\
\quad(+16.65)\end{array}$ & $\begin{array}{c}233.33 \pm 2.25^{c} \\
(+23.34)\end{array}$ \\
\hline Group II & $192.50 \pm 2.14$ & $179.33 \pm 2.29$ & $\begin{array}{c}169.33 \pm 1.96^{\mathrm{a}} \\
(-5.57)\end{array}$ & $\begin{array}{c}162.50 \pm 1.78^{c} \\
(-9.38)\end{array}$ & $\begin{array}{c}155.17 \pm 1.68^{c} \\
(-13.47)\end{array}$ & $\begin{array}{c}151.33 \pm 3.23^{c} \\
(-15.61)\end{array}$ \\
\hline Group III & $194.00 \pm 2.78$ & $180.17 \pm 2.36$ & $\begin{array}{c}181.67 \pm 2.11^{\mathrm{ns}} \\
(+0.83)\end{array}$ & $\begin{array}{c}183.00 \pm 1.90^{\text {ns }} \\
(+1.57)\end{array}$ & $\begin{array}{c}186.17 \pm 2.04^{\mathrm{ns}} \\
\quad(+3.33)\end{array}$ & $\begin{array}{c}190.33 \pm 2.29^{\mathrm{a}} \\
(+5.63)\end{array}$ \\
\hline Group IV & $193.83 \pm 1.90$ & $181.00 \pm 2.10$ & $\begin{array}{c}183.33 \pm 2.12^{\mathrm{ns}} \\
(+1.28)\end{array}$ & $\begin{array}{c}187.67 \pm 2.97^{\mathrm{ns}} \\
(+3.68)\end{array}$ & $\begin{array}{c}192.50 \pm 3.19^{\mathrm{a}} \\
(+6.07)\end{array}$ & $\begin{array}{c}196.33 \pm 3.07^{\mathrm{b}} \\
(+8.46)\end{array}$ \\
\hline Group V & $187.50 \pm 3.34$ & $172.50 \pm 2.49$ & $\begin{array}{c}178.67 \pm 3.01^{\mathrm{ns}} \\
(+3.57)\end{array}$ & $\begin{array}{c}186.83 \pm 2.91^{\mathrm{a}} \\
\quad(+8.33)\end{array}$ & $\begin{array}{c}189.67 \pm 4.48^{\mathrm{a}} \\
(+9.95)\end{array}$ & $\begin{array}{c}194.83 \pm 3.43^{c} \\
(+12.94)\end{array}$ \\
\hline Group VI & $188.00 \pm 2.44$ & $177.17 \pm 3.02$ & $\begin{array}{c}183.17 \pm 2.76^{\mathrm{ns}} \\
(+3.38)\end{array}$ & $\begin{array}{c}190.83 \pm 2.61^{\mathrm{a}} \\
\quad(+7.71)\end{array}$ & $\begin{array}{c}195.33 \pm 3.57^{\mathrm{b}} \\
(+10.25)\end{array}$ & $\begin{array}{c}202.50 \pm 4.25^{c} \\
\quad(+14.29)\end{array}$ \\
\hline
\end{tabular}

Level of significance:

Value in parenthesis indicate $\%$ change

Values represent mean $\pm \operatorname{SEM}(n=6)$

$\mathrm{ns}=$ non significant; $\mathrm{a}=\mathrm{P} \leq 0.05 ; \mathrm{b}=\mathrm{P} \leq 0.01 ; \mathrm{c}=\mathrm{P} \leq 0.001$, normal control, diabetic control, $C$. fistula extract and glibenclamide treated rats compared with their corresponding values on 0 day. 
Jangir et al.: Antidiabetic activity of Cassia fistula pod in STZ-induced diabetic rats

Table 2: Effects of $C$. fistula pod extract on fasting blood glucose (mg/dL) in STZ-induced diabetic rats

\begin{tabular}{|c|c|c|c|c|c|c|}
\hline Treatment & $\begin{array}{c}\text { STZ } \\
\text { treatment } \\
\text { day }\end{array}$ & $0^{\text {th }}$ Day & $15^{\text {th }}$ Day & $30^{\text {th }}$ Day & $45^{\text {th }}$ Day & $60^{\text {th }}$ Day \\
\hline Group I & $81.66 \pm 1.47$ & $84.17 \pm 1.92$ & $\begin{array}{c}82.50 \pm 2.29^{\text {ns }} \\
(-1.98)\end{array}$ & $\begin{array}{c}85.33 \pm 1.84^{\text {ns }} \\
(+1.38)\end{array}$ & $\begin{array}{c}83.00 \pm 3.10^{\mathrm{ns}} \\
(-1.39)\end{array}$ & $\begin{array}{c}81.50 \pm 1.67^{\mathrm{ns}} \\
(-3.17)\end{array}$ \\
\hline Group II & $83.17 \pm 1.58$ & $335.33 \pm 10.47$ & $\begin{array}{c}353.50 \pm 9.39^{\mathrm{ns}} \\
(+5.42)\end{array}$ & $\begin{array}{c}367.00 \pm 10.68^{\mathrm{ns}} \\
(+9.44)\end{array}$ & $\begin{array}{c}379.83 \pm 12.41^{\mathrm{a}} \\
(+13.27)\end{array}$ & $\begin{array}{c}390.33 \pm 10.42 \\
(+16.40)\end{array}$ \\
\hline Group III & $79.83 \pm 1.54$ & $324.33 \pm 13.75$ & $\begin{array}{c}286.67 \pm 16.90^{\mathrm{ns}} \\
(-13.14)\end{array}$ & $\begin{array}{c}246.50 \pm 12.85^{\mathrm{a}} \\
(-23.99)\end{array}$ & $\begin{array}{c}217.50 \pm 9.67^{c} \\
(-32.93)\end{array}$ & $\begin{array}{c}203.50 \pm 10.47 \\
(-37.25)\end{array}$ \\
\hline Group IV & $84.67 \pm 1.76$ & $330.50 \pm 9.93$ & $\begin{array}{c}275.83 \pm 14.30^{\mathrm{a}} \\
(-16.54)\end{array}$ & $\begin{array}{c}208.83 \pm 10.07^{\mathrm{b}} \\
\quad(-36.81)\end{array}$ & $\begin{array}{c}196.17 \pm 10.15^{c} \\
(-40.64)\end{array}$ & $\begin{array}{c}185.17 \pm 9.84^{c} \\
(-43.97)\end{array}$ \\
\hline Group V & $83.50 \pm 1.78$ & $319.17 \pm 12.40$ & $\begin{array}{c}248.67 \pm 11.80^{\mathrm{b}} \\
(-22.09)\end{array}$ & $\begin{array}{c}188.67 \pm 12.62^{\mathrm{c}} \\
(-40.89)\end{array}$ & $\begin{array}{c}171.17 \pm 11.44^{\mathrm{c}} \\
(-46.37)\end{array}$ & $\begin{array}{c}159.17 \pm 10.52 \\
(-50.13)\end{array}$ \\
\hline Group VI & $78.67 \pm 2.25$ & $331.83 \pm 14.03$ & $\begin{array}{c}203.17 \pm 14.99^{\mathrm{c}} \\
(-38.77)\end{array}$ & $\begin{array}{c}154.83 \pm 13.83^{c} \\
(-53.34)\end{array}$ & $\begin{array}{c}128.33 \pm 9.59^{c} \\
(-61.32)\end{array}$ & $\begin{array}{c}119.33 \pm 10.39 \\
(-62.84)\end{array}$ \\
\hline
\end{tabular}

Level of significance: Value in parenthesis indicate \% change Values represent mean $\pm \operatorname{SEM}(n=6)$

$\mathrm{ns}=$ non significant; $\mathrm{a}=\mathrm{P} \leq 0.05 ; \mathrm{b}=\mathrm{P} \leq 0.01 ; \mathrm{c}=\mathrm{P} \leq 0.001$, normal control, diabetic control, C.fistula extract and glibenclamide treated rats compared with corresponding values on 0 day.

level in normal control rats (group I) tend to return near normal level. The untreated diabetic rats (group II) showed maximum increase in blood glucose after $60 \mathrm{~min}$ and mild decline after $90 \mathrm{~min}$. In diabetic rats treated with $500 \mathrm{mg} / \mathrm{kg}$ b.wt. of C. fistula extract (group V) or glibenclamide (group VI), the blood glucose level showed continues decline after $60 \mathrm{~min}$ and after $120 \mathrm{~min}$ the level reached to near initial value at 0 min.

\section{Total hemoglobin, glycosylated hemoglobin and glycogen}

Figures 2-4 shows the levels of total hemoglobin $(\mathrm{Hb})$, glycosylated hemoglobin (HbAlc) and hepatic glycogen respectively, in normal control, diabetic control and all experimental groups. The diabetic control rats (group II) showed a significant $(\mathrm{P} \leq 0.001)$ decrease in the levels of hepatic glycogen and total hemoglobin $(\mathrm{Hb})$ with a concomitant significant $(\mathrm{P} \leq 0.001)$ increase in the percentage of glycosylated hemoglobin (HbA1c) in blood as compared to normal control rats (group I). Diabetic rats treated with different doses of C. fistula pod extract (100, 250 and $500 \mathrm{mg} / \mathrm{kg}$ b.wt./day) or glibenclamide showed significant increase in the levels of hepatic glycogen [group III ( $\mathrm{P} \leq 0.05)$, group IV, $\mathrm{V}$ and VI $(\mathrm{P} \leq 0.001)$ ] and total $\mathrm{Hb}$ level in blood [group IV $(\mathrm{P} \leq 0.01)$, group $\mathrm{V}$ and $\mathrm{VI}(\mathrm{P} \leq 0.001)]$ when compared to diabetic control rats. In contrast to this, the percentage of $\mathrm{HbAlc}$ in blood was significantly decreased [group III $(\mathrm{P} \leq 0.05)$, group IV, V and VI $(\mathrm{P} \leq 0.001)$ ] as compared to diabetic control rats.

\section{DISCUSSION}

Body weight is an indicator of good health and efficient metabolic homeostasis. The body weight of normal control rat showed a progressive increase throughout the experimental period. However, the body weight of untreated diabetic rats was found to be significantly decreased with increasing the duration of treatment. These results are in agreement with previous finding where similar decline in the body weight was recorded in STZ-induced diabetic rats. ${ }^{45-47}$ The observed body weight loss in diabetic rats might be due to dehydration and excessive breakdown of tissue proteins and fats. Increased catabolism leading to muscle wasting might also be responsible for body weight loss. ${ }^{46,48}$ Subchronic treatment of C. fistula pod extract at different doses $(100,250,500 \mathrm{mg} / \mathrm{kg})$ in

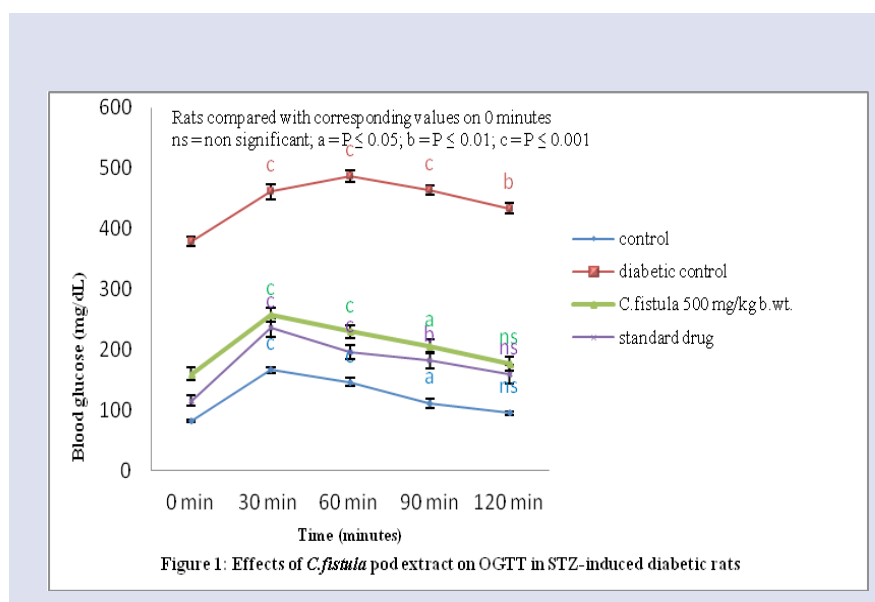

Figure 1: Effects of $C$. fistula pod extract on OGTT in STZ-induced diabetic rats

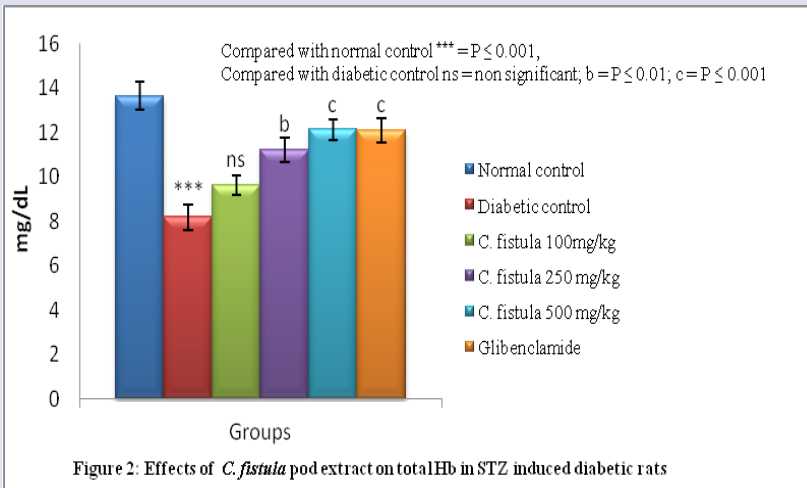

Figure 2: Effects of $C$. fistula pod extract on total $\mathrm{Hb}$ in STZ induced diabetic rates 


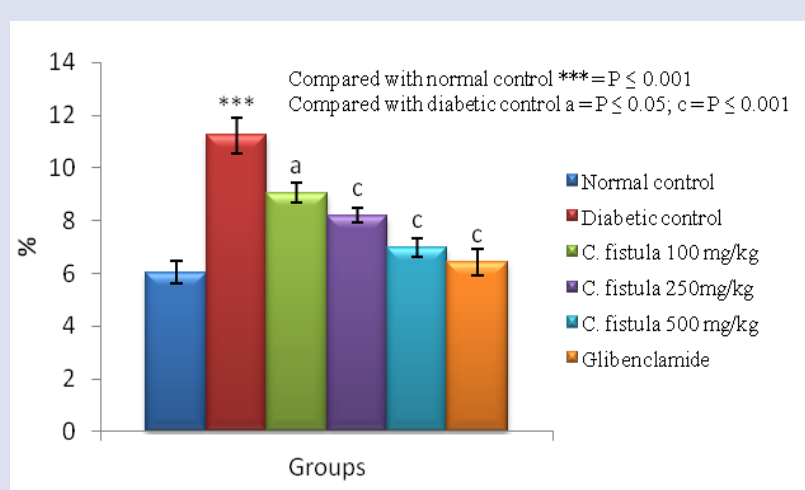

Figure 3: Effects of C. fistula pod extract on $\mathrm{HbA1c}$ in STZ induced diabetic rats

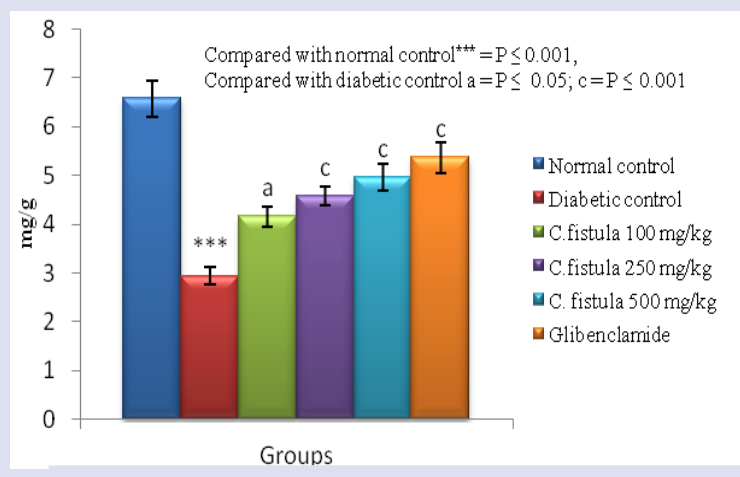

Figure 4: Effects of $C$. fistula pod extract on heptic glycogen in STZ induced diabetic rats

diabetic rats prevented the loss of body weight in both dose and duration dependent fashion. These observations are parallel with the finding of other workers who also reported a similar prevention of body weight loss in diabetic rats after administration of C. fistula extract. ${ }^{[37,42,46]}$ This might be due to efficient, better glycemic and metabolic homeostasis and prevention of muscles waisting induced by the plant extract. ${ }^{49}$

Streptozotocin is broad spectrum antibiotic and is widely used chemical for the induction of experimental diabetes in animals. STZ selectively destroys the pancreatic beta cells involving uptake of glucose by glucose transporter -2 (GLUT-2). It also generates reactive oxygen species (ROS), which contribute to DNA fragmentation and evokes other deleterious changes in the beta cells of pancreas ultimately inducing beta cell necrosis and depletion of insulin biosynthesis and secretion resulting in hyperglycemia. ${ }^{50-52}$ This was evident from the marked increase in the fasting blood glucose levels in STZ treated diabetic control rats in the present study. These results are parallel with other reports which have also observed depletion of plasma insulin level and significant elevation in fasting blood glucose level in streptozotocin treated diabetic rats. ${ }^{34,35,47,53}$

Administration of glibenclamide or C. fistula pod extract at different doses for 60 days in STZ-induced diabetic rats showed significant reduction in the fasting blood glucose levels. These results are parallel with previous reports which have also showed a significant decline in blood glucose levels of diabetic rats after treatment with extract of C. fistula fruit pulp, ${ }^{42}$ leaves, ${ }^{38,54}$ bark, ${ }^{34,35}$ flowers, ${ }^{40,41}$ and root. ${ }^{33}$ The reduction of fasting blood glucose level by $C$. fistula pod extract may be due to its many potential bioactive phytochemicals especially rhein glycosides, fistulic acid, sennosides A \& B, anthoquinones, flavon-3-ol derivatives, kaempferol, proanthocyanidins like catechin, epiafzelechin, epicatechin and procyanidin ${ }^{25}$ and quercetin dehydrates. ${ }^{19}$ The seed contains oxyanthraquinones, chrysophanol and chrysophanein. ${ }^{32}$

The antihyperglycemic effect of $C$. fistula pod extract might be by virtue of individual or synergistic effects of the phytoconstituents resulting in stimulation of insulin from remnant pancreatic $\beta$-cells or insulin mimetic effects which in turn stimulates glucose utilization by hepatic and extra hepatic tissues of the diabetic rats. In addition to this, the extract may cause inhibition of glucose absorption in the gut. ${ }^{35,38,39,54}$ Daisy et al, (2010) reported that catechin isolated from methanolic extract of C. fistula bark has significant hypoglycemic and insulin mimetic effect in STZ-induced diabetic rats. ${ }^{35}$ Previous studies conclusively have shown that phytochemicals like, proanthrocynadins, ${ }^{55}$ kaempferol, ${ }^{56}$ quercetin $^{57,58}$ and anthroqunone derivatives ${ }^{59,60}$ possess hypoglycemic effects in the diabetic animals. It is well established that $C$. fistula pod is rich source of antioxidants. ${ }^{61}$ which scavenge hyperglycemia induced free radicals and exhibit $\beta$-cells protective effect.

Oral glucose tolerance test is well accepted and frequently used assay to screen anti hyper glycemic activity of any $\mathrm{drug}^{62}$ and also to identity the altered carbohydrate metabolism during post glucose administration..$^{53}$ The results of oral glucose tolerance test suggest that rats treated with C. fistula pod extract (500 $\mathrm{mg} / \mathrm{kg}$ b.wt) have better glucose utilization capacity. This action could be due to enhanced insulin secretion from the beta cells, improved glucose utilization and transport..$^{63}$ These results are consistent with earlier finding which have also reported significant improvement in oral glucose tolerance in C. fistula extract treated diabetic rats. ${ }^{41,64}$ Glycosylated hemoglobin is considered as the most reliable marker of glycemic control in the body. ${ }^{65}$ Glycation is a post translational non-enzymatic addition of sugar residues to $\mathrm{N}$-terminal end of the hemoglobin beta chain. The rate of synthesis of $\mathrm{HbAlc}$ is directly related to exposure of $\mathrm{RBC}$ to glucose. ${ }^{66} \mathrm{HbAlc}$ is formed progressively and irreversibly over a period of time and it stable till the life of RBC. During diabetes, the excess glucose present in the blood reacts with hemoglobin. Therefore, the total hemoglobin level is decreased with concomitant increase in the percentage of glycosylated hemoglobin (HbAlc) in the blood of streptozotocin induced diabetic rats as observed during present study. Our results are supported by the earlier findings which have also observed significant increase in HbA1c level in STZ diabetic rats. ${ }^{34,38,47,67}$ Administration of C. fistula pod extract or glibenclamide in diabetic rats significantly prevented the rise in glycosylated hemoglobin (HbAlc) level and increased the levels of total hemoglobin in blood. This might be the result of an improvement of the glycemic control in the body. These results are corroborated by earlier reports which have also reported decline of glycosylated hemoglobin levels thereby increasing the levels of total hemoglobin in diabetic rats treated with extract of C. fistula leaves, ${ }^{38,39}$ bark $^{34,46,66}$ and flower. ${ }^{40,41}$

Liver plays a crucial role in maintaining the blood glucose homeostasis. Insulin regulates glucose metabolism in the liver by stimulating glycolysis, glycogenesis and inhibiting gluconeogenesis. Glycogen synthase and glycogen phosphorylase are two key regulatory enzymes that catalyze the rate limiting steps of glycogenesis and glycogenolysis respectively. ${ }^{35,68}$ Insulin favours glycogen synthesis by means of stimulation of glycogen synthase and hindering glycogen phosphorylase. The reduced hepatic glycogen content observed in streptozotocin induced diabetic rats in the present study may be correlated with insulin insufficiency and/ or defect in insulin action. These results are parallel with the previous findings where similar decline in glycogen contents in liver was observed in diabetic animals. ${ }^{38,47,53}$ When diabetic rats were treated with different doses of $C$. fistula pod extract, a significant dose dependent increase in 
Jangir et al.: Antidiabetic activity of Cassia fistula pod in STZ-induced diabetic rats

hepatic glycogen reserve was observed indicating enhanced rate of glycogenesis probably by virtue of insulin secretagogue or insulin mimetic activity of the extract which may enhance uptake of glucose in hepatic cells or by forcing the activities of enzymes that are involved in glycogen synthesis. These results are in agreement with previous studies which have also shown significant increase in glycogen content of liver after treatment of STZ-induced diabetic rats with C. fistula leaves ${ }^{38,54}$ and bark extract. ${ }^{35}$ The observed anti-diabetic effects of $C$. fistula pod extract were comparable to the standard drug glibenclamide.

\section{CONCLUSION}

The results of present study showed that $70 \%$ ethanolic extract of C. fistula pod effectively lowered fasting blood glucose levels and glycosylated hemoglobin in blood and increased glycogen store in the liver of STZ-induced diabetic rats suggesting improved glycemic control in diabetic state and supports the traditional use of the C. fistula pod in management of diabetes mellitus.

\section{ACKNOWLEDGEMENT}

The authors are thankful to Head, Department of Zoology, University of Rajasthan, Jaipur for providing necessary facilities and also to University Grants Commission, New Delhi for the award of Emeritus Fellowship to Prof. G. C. Jain.

\section{CONFLICT OF INTEREST}

There are no conflicts of interest.

\section{ABBREVIATIONS USED}

b.wt.: Body weight; C. fistula: Cassia fistula; DM: Diabetes mellitus; Hb: Hemoglobin; HbA1c: Glycosylated hemoglobin; OGTT: Oral Glucose Tolerance Test; RBC: Red Blood Cell; STZ: Streptozotocin.

\section{REFERENCES}

1. American Diabetes Association (ADA). Diagnosis and classification of diabetes mellitus. Diabetes Care. 2011;34 Suppl 1:62-9. https://doi.org/10.2337/dc11-S062 PMid:21193628 PMCid:PMC3006051.

2. International Diabetes Federation. Diabetes Atlas. Sixth edition. 2013.

3. World Health Organization. Global status report on non-communicable diseases 2010. Geneva. 2011; pp. 1-176

4. Dewanjee S, Das AK, Sahu R, Gangopadhyay M. Antidiabetic activity of Diospyros peregrina fruit: effect on hyperglycemia, hyperlipidemia and augmented oxidative stress in experimental type 2 diabetes. Food Chem Toxicol. 2009;47(10):2679-85. https://doi.org/10.1016/j.fct.2009.07.038; PMid:19660513.

5. Saxena A, Vikram NK. Role of selected Indian plants in management of type 2 diabetes: a review. J Altern Complement Med. 2004;10(2):369-78. https://doi. org/10.1089/107555304323062365; PMid:15165418.

6. Arumugam G, Manjula P, Paari N. A review: Anti diabetic medicinal plants used for diabetes mellitus. J Acute Dis. 2013;2(3):196-200. https://doi.org/10.1016/ S2221-6189(13)60126-2.

7. Noor A, Bansal VS, Vijayalakshmi MA. Current update on anti-diabetic biomolecules from key traditional Indian medicinal plants. Curr Sci. 2013;104(6):721-7.

8. Chopra RN, Nayar SL, Chopra IC. Glossary of Indian medicinal plants, Publication and information Directorate, CSIR, New Delhi. 1992:54.

9. Barthakur NN, Arnold NP, Alli I. The Indian laburnum (Cassia fistula L.) fruit: an analysis of its chemical constituents. Plants Food Hum Nutr. 1995;47(1):55-62. https://doi.org/10.1007/BF01088167.

10. Parrotta JA. Healing Plants of Peninsular India, CABI Publishing, New York: USA, p. 332-4;

11. Kulkarni A, Govindappa M, Ramachandra YL, Koka P. GC-MS analysis of methanol extract of Cassia fistula and its in vitro anticancer activity on human prostate cancer cell line. Indo Am J Pharm Res. 2015;5(2):937-44.

12. Yadav R, Jain GC. Antifertility effect of aqueous extract of seeds of Cassia fistula in female rats. Adv Contracept. 1999;15(4):293-301. https://doi. org/10.1023/A:1006784224191; PMid:11145371.

13. War IR, Ganie SA, Agnihotri RK, Sharma B, Mahajan S, Sharma R. Antifungal activity of Cassia fistula linn against some pathogenic fungi. International Journal of Phytomedicine. 2014;6(2):182-7.
14. Irshad M, Singh M, Rizvi MA. Assessment of anthelmintic activity of Cassia fistula. Middle East J Sci Res. 2010;5(5):346-9

15. Gupta UC, Jain GC. Study on hypolipidemic activity of Cassia fistula. Legume in rats: Asian J Exp Sci. 2009;23(1):241-8.

16. Bhakta T, Mukherjee PK, Saha K, Pal M, Saha BP, Mandal SC. Evaluation of anti-inflammatory effects of Cassia fistula (Leguminosae) leaf extract on rats. J Herbs Spices Med Plants. 2000;6(4):67-72. https://doi.org/10.1300/ J044v06n04_08.

17. Gobianand K, Vivekanandan P, Pradeep K, Mohan CVR, Karthikeyan S. Antiinflammatory and antipyretic activities of Indian medicinal plant Cassia fistula Linn. (Golden shower) in Wistar albino rats. Int J Pharmacol. 2010;6(6):719-25. https://doi.org/10.3923/ijp.2010.719.725

18. Manonmani G, Bhavapriya V, Kalpana S, Govindasamy S, Apparanantham T. Antioxidant activity of Cassia fistula (Linn.) flowers in alloxan induced diabetic rats. J Ethnopharmacol. 2005;97(1):39-42. https://doi.org/10.1016/j.jep.2004.09.051. PMid:15652272.

19. Laxmi V, Bhatia AK, Goel A, Wahi N, Sharma A. Phytochemicals screening and analysis using HPLC to determine the antimicrobial efficacy of Cassia fistula extract. Adv Biores. 2015;6(3):1-7.

20. Sharma E, Chandel M, Meerwal P, Jangir RN, Jain GC, Pareek H, et al. Therapeutic potential of Cassia fistula pod extract in amelioration of carbon tetra cloride induced liver toxicity. Indian J Fund Appl Life Sci. 2016;6:123-31.

21. Jadhav SN. Evaluation of immunomodulatory activity of Cassia fistula. Int J Pharm Chem Biol Sci. 2014;3:291-3

22. Akanmu MA, Iwalewa EO, Elujoba AA and Adelusola KA. Toxicity potentials of Cassia fistula fruits as laxative with reference to senna. Afr J Biomed Res. 2004;7(1):23-6.

23. Sayeed AM, Ali AM, Khan GA, Rahman MS. Studies on the characterization and glyceride composition of Cassia fistula seed oil. Bangladesh J Sci Indust Res. 1999;34(1):144-8

24. Lal J, Gupta PC. Partial hydrolysis and the structure of the galatomannan from Cassia fistula seeds. Planta Med. 1976;30(08):378-83. https://doi. org/10.1055/s-0028-1097747.

25. Kashiwada Y, lizuka H, Toshika K, Chen R, Nonaka G, Nishioka I. Tannins and related compounds. XCIII. Occurrence of enantiomeric proanthocyanidins in the Leguminosae plants, Cassia fistula L.; Cassia Javanica L. Chem Pharm Bull. 1990;38(4):888-93. https://doi.org/10.1248/cpb.38.888

26. Modi FK, Khorana ML. A study of Cassia fistula pulp. Indian J Pharm. 1952:4:61-3.

27. Agrawal GD, Rizvi SAI, Gupta PC, Tewari JD. Structure of fistulic acid a new colouring matter from the pods of Cassia fistula. Planta Med. 1972;21(02):150-5. https://doi.org/10.1055/s-0028-1099536; PMid:5018491.

28. Rani M, Kalidhar SB. A new anthraquinone derivative from Cassia fistula Linn. pods. Indian J Chem 37B. 1998;37(12):1314-5.

29. Misra TN, Singh RS, Pandey HS, Singh BK. A new diterpene from Cassia fistula pods. Fitoterapia. 1997:68(4):375-6.

30. Misra TN, Singh RS, Pandey HS, Pandey RP. Chemical constituents of hexane fraction of Cassia fistula pods. Fitoterapia LXVII. 1996;67(2):173-4

31. Rastogi RP, Mehrotra BN. Compendium of Indian Medicinal plants, Central Drug Research Institute, Lucknow and National Institute of Science Communication and Information Resources, New Delhi, 2004;(3)140.

32. Kuo $H$, Lee PH, Wein YS. Four new compounds from the seeds of Cassia fistula. J Nat Prod. 2002:65(8):1165-7. https://doi.org/10.1021/np020003k: PMid:12193023

33. Balraj S, Indumathy R, Jayshree N, Abirami MS. Evaluation of invitro anti-diabetic activity of various root extract of Cassia fistula L. Imperial Journal of Interdisciplinary Research (IJIR). 2016;2(6):758-61.

34. Nirmala A, Eliza J, Rajalakshmi M, Priya E, Daisy P. Effect of hexane extract of Cassia fistula barks on blood glucose and lipid profile in streptozotocin diabetic rats. Int J Pharmcol. 2008;4(4):292-6. https://doi.org/10.3923/ijp.2008.292.296.

35. Daisy P, Balasubramanian K, Rajalakshmi M, Eliza J, Selvaraj J. Insulin mimetic impact of catechin isolated from Cassia fistula on the glucose oxidation and molecular mechanisms of glucose uptake on streptozotocin-induced diabetic Wistar rats. Phytomedicine. 2010;17(1):28-36. https://doi.org/10.1016/j.phymed. 2009.10.018; PMid:19931438

36. Malpani SN, Manjunath KP, Sholapur H, Savadi RV, Akki KS, Darade SS Antidiabetic activity of Cassia fistula Linn. bark in alloxan induced diabetic rats. International Journal of Pharmaceutical Sciences and Research. 2010:2(1):382-5.

37. Agnihotri A, Singh V. Effect of Tamarindus indica linn. and Cassia fistula linn. stem bark extracts on oxidative stress and diabetic conditions. Acta Poloniae Pharmaceutica - Drug Research. 2013;70(6):1011-9.

38. Vasudevan K, Manoharan S, Panjamurthy K, Vellaichamy L, Chellammal A Evaluation of antihyperglycemic effect of Cassia fistula (linn.) leaves in streptozotocin induced diabetic rats. Electronic Journal of Pharmacology and Therapy. 2008;1:57-60

39. Einstein JW, Rais MM, Mohd AM. Comparative evaluation of the antidiabetic effects of different parts of Cassia fistula Linn, a Southeast Asian plant. Journal of Chemistry. 2013;2013:1-10. https://doi.org/10.1155/2013/714063.

40. Jeyanthi KA. Beneficial effect of Cassia fistula (I) flower extract on antioxi- 
dant defense in streptozotocin induced diabetic rats. Int J Pharm Pharm Sci, 2012;4:274-6.

41. Jarald EE, Joshi SB, Jain DC, Edwin S. Biochemical evaluation of the hypoglycemic effects of extract and fraction of Cassia fistula Linn. in alloxan-induced diabetic rats. Indian J Pharm Sci. 2013;75(4):427-34. https://doi.org/10.4103/ 0250-474X.119823; PMid:24302797 PMCid:PMC3831724.

42. Akhila S, Aleykutty NA. Antidiabetic activity studies on Cassia fistula fruits. Adv J Pharm Life Sci Res. 2015;3:1-8.

43. Ayurvedic Pharmacopoeia of India, Part 1, Vol.5, New Delhi, Government of India Publication, 2001. pp 8-9. PMCid:PMC3300515.

44. Montgomery R. Determination glycogen. Arch Biochem Biophys. 1957;67(2): 378-86. https://doi.org/10.1016/0003-9861(57)90292-8.

45. Adiga S, Bairy KL, Meharban A, Punita IS. Hypoglycemic effect of aqueous extract of Trichosanthes dioica in normal and diabetic rats. Int J Diabetes Dev Ctries. 2010;30(1sa):38-42. PMid:20431805 PMCid:PMC2859283.

46. Daisy P, Saipriya K. Biochemical analysis of Cassia fistula aqueous extract and phytochemically synthesized gold nanoparticles as hypoglycemic treatment for diabetes mellitus. Int J Nanomedicine. 2012:7;1189-202. https://doi. org/10.2147/IJN.S26650; PMid:22419867 PMCid:PMC3299574.

47. Jayaprasad B, Sharavanan PS, Sivaraj R. Antidiabetic effect of Chloroxylon swietenia bark extracts on streptozotocin induced diabetic rats. Beni-Suef University Journal of Basic and Applied Sciences. 2016;5(1):61-9. https://doi. org/10.1016/j.bjbas.2016.01.004

48. Hakkim FL, Girija S, Kumar RS, Jalaludeen MD. Effect of aqueous and ethanol extracts of Cassia auriculata L. flowers on diabetes using alloxan induced diabetic rats. Int J Diabetes \& Metabolism. 2007;15:100-6.

49. Pareek H, Sharma S, Khajja BS, Jain K, Jain GC. Evaluation of hypoglycemic and anti-hyperglycemic potential of Tridax procumbens (Linn.). BMC Complementary and Alternative Medicine, 2009;9:48. Available from: http://www. biomedcentral.com/1472-6882/9/48. https://doi.org/10.1186/1472-6882-9-48 ; PMid:19943967 PMCid:PMC2790435.

50. Szkudelski T. The mechanism of alloxan and streptozotocin action in B cells of the rat pancreas. Physiol Res. 2001;50(6):537-46. PMid:11829314.

51. Lenzen S. The mechanisms of alloxan- and streptozotocin-induced diabetes Diabetologia. 2008;51(2):216-26. https://doi.org/10.1007/s00125-007-0886-7 PMid:18087688.

52. Wu J, Yan LJ. Streptozotocin-induced type 1 diabetes in rodents as a model for studying mitochondrial mechanisms of diabetic $\beta$ cell glucotoxicity. Diabetes Metab Syndr Obes. 2015;8:181-8. PMid:25897251 PMCid:PMC4396517.

53. Kumar V, Ahmed D, Gupta PS, Anwar F, Mujeeb M. Anti-diabetic, anti-oxidant and anti-hyperlipidemic activities of Melastoma malabathricum linn. leaves in streptozotocin induced diabetic rats. BMC Complement Altern Med. 2013;13:222. Available from: http://www.biomedcentral.com/1472-6882/13/222. https://doi. org/10.1186/1472-6882-13-222 ; PMid:24010894 PMCid:PMC3847142.

54. Silawat N, Jarald EE, Jain N, Yadav A, Deshmukh PT. The mechanism of hypoglycemic and antidiabetic action of hydroalcholic extract of Cassia fistula Linn. in rats. The Pharma. 2009;1:82-92.
55. Yokozawa T, Cho EJ, Park CH, Kim JH. Protective effect of proanthocyanidin against diabetic oxidative stress. Evid Based Complement Alternat Med. 2012;2012. Available from http://dx.doi.org/10.1155/2012/623879. https://doi. org/10.1155/2012/623879.

56. Luangpiom A, Kourjampa W, Junaimaung T. Anti-hyperglycemic properties of Moringa oleifera lam. aqueous leaf extract in normal and mildly diabetic mice. Br J Pharmacol Toxicol. 2013;4(3):106-9.

57. Ali FT, Hassan NS, Abdrabou RR. Potential activity of Moringa oleifera leaf extract and some active ingredients against diabetes in rats. Int J Sci Eng Res. 2015;6(5):1490.

58. Jangir RN, Jain GC. Antidiabetic and antioxidant potential of hydroalcoholic extract of Moringa oleifera leaves in streptozotocin-induced diabetic rats. European Journal of Pharmaceutical and Medical Research. 2016;3:438-50.

59. Lee MS and Sohn CB. Anti-diabetic properties of chrysophanol and its glucoside from rhubarb rhizome. Biol Pharm Bull. 2008:31(11):2154-7. https://doi. org/10.1248/bpb.31.2154; PMid:18981591.

60. Choi SZ, Lee SO, Jang KU, Chung SH, Park SH, Kang HC, Yang EY, Cho HJ, Lee KR. Antidiabetic stilbene and anthraquinone derivatives from Rheum undulatum. Arch Pharm Res. 2005;28:1027-30. https://doi.org/10.1007/BF02977396; PMid:16212232

61. Luximon-Ramma A, Bahorun T, Soobrattee MA, Aruoma OI. Antioxidant activities of phenolic, proanthocyanidin, and flavonoid components in extracts of Cassia fistula. J Agric Food Chem. 2002;50(18):5042-7. https://doi.org/10.1021/jf0201172; PMid:12188605.

62. Alberti KG, Zimmet PZ. Definition, diagnosis and classification of diabetes mellitus and its complications. Part 1: diagnosis and classification of diabetes mellitus provisional report of a WHO consultation. Diabet Med. 1998;15:539-53. https:// doi.org/10.1002/(SICI)1096-9136(199807)15:7<539::AID-DIA668>3.0.CO;2-S

63. Hui $H$, Tang G, GoWVL. Hypoglycemic herbs and their action mechanisms. Chin Med. 2009;4(1):11-4. https://doi.org/10.1186/1749-8546-4-11; PMid:19523223 PMCid:PMC2704217.

64. Ashraf AM, Sagar HA, Sultana MC, Azad AK, Begum K, Wahed MII. Antihyperglycemic and analgesic activities of ethanolic extract of Cassia fistula (L.) stem bark. Int J Pharm Sci Res. 2012;3:416-23.

65. Lyons TJ, Basu A. Biomarker in diabetes: hemoglobin A1c, vascular and tissue markers. NIH Public Access. 2012;159(4):303-12. https://doi.org/10.1016/j. trsl.2012.01.009

66. Kaleem M, Medha P, Ahmed QU, Asif M, Bano B. Beneficial effects of ss extract in streptozocin induced diabetic rats. Singapore Med. 2008;49(10):800-4.

67. Giribabu N, Kumar KE, Rekha SS, Muniandy S, Salleh N. Chlorophytum borivilianum root extract maintains near normal blood glucose, insulin and lipid profile levels and prevents oxidative stress in the pancreas of streptozotocininduced adult male diabetic rats. Int J Med Sci. 2014;11(11):1172-84. https://doi. org/10.7150/ijms.905; PMid:25249786 PMCid:PMC4166863.

68. Stalmans W, Bollen M, Mvumbi L. Control of glycogen synthesis in health and disease. Diabetes Metab Rev. 1987;3:127-61. https://doi.org/10.1002/ dmr.5610030107; PMid:3032540.

\section{GRAPHICAL ABSTRACT}

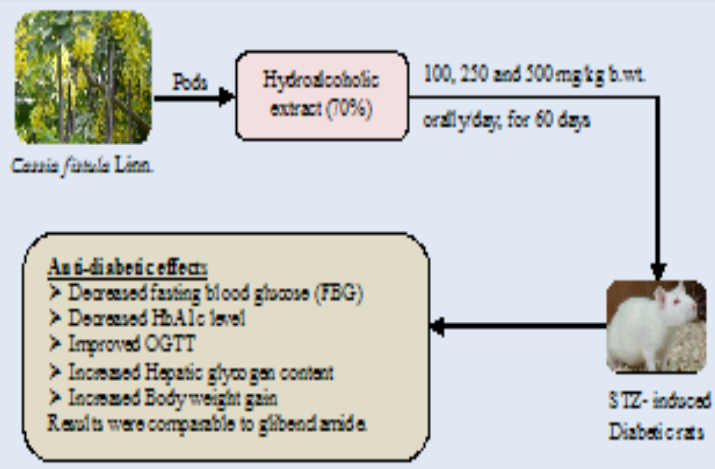

\section{HIGHLIGHTS OF PAPER}

- Antidiabetic activity of $70 \%$ ethanolic extract of $C$. fistula Linn. podin STZ-induced diabetic rats was studied.

- Extract treatment in STZ- diabetic rat significantly restored body weight.

- Theextractalsoshowedsignificantreductioninfastingbloodglucose, glycosylated hemoglobin $(\mathrm{HbA} 1 \mathrm{c})$ levels and improvement in OGTT.

- Hepatic glycogen store was also increased significantly in extract treated STZdiabetic rats.

- The anti-hyperglycemic effect of the extract was comparable with standard drug glibenclamide and supports the traditional use of $C$. fistula pod in the management of diabetes mellitus. 


\section{AUTHOR PROFILE}

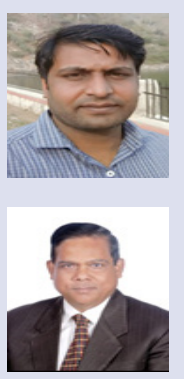

Ram Niawas Jangir: Holds a master degree in Zoology and currently he is carrying out research work for $\mathrm{Ph}$. D. degree on medicinal plants possessing antidiabetic potential at Department of Zoology, University of Rajasthan, Jaipur (India).

Gyan Chand Jain: Is former Professor \& Head and Coordinator UGC-CAS (phase-II) program, Department of Zoology, University of Rajasthan, Jaipur. Presently he is pursuing the on going research program on the effects of environmental pollutants on health and their mitigation using natural products and also identifying the phytochemicals from various plants for antidiabetic, contraceptive and other activities.

Cite this article : Jangir RN, Jain GC. Evaluation of antidiabetic activity of hydroalcoholic extract of Cassia fistula Linn. pod in streptozotocin-induced diabetic rats. Pharmacog J. 2017;9(5):599-606. 